on the Presentation on Demand (POD) System, a network of computer stations distributed throughout the meeting area that permits attendees to review PowerPoint and Video presentations on demand.

\section{CALL FOR ABSTRACTS}

Abstract Deadline is Friday, December 9, 2011

To submit your abstract visit www.aats.org/aortic

\section{TARGET AUDIENCE}

This conference is designed to meet the educational needs of cardiovascular and thoracic surgeons, residents, perfusionists, ICU and OR nurses, and those involved with the care of individuals with aortic disease.

\section{ACCREDITATION}

The American Association for Thoracic Surgery is accredited by the Accreditation Council for Continuing Medical Education to provide continuing medical education for physicians.

This live activity has been approved for AMA PRA Category 1 Credits $^{\mathrm{TM}}$.

\section{AATS 92nd Annual Meeting}

April 28-May 2, 2012

(Immediately following the Aortic Symposium 2012 in New York, NY)

Moscone West Convention Center

San Francisco, CA

Save the Date!

Join us at the Moscone West Convention Center in San Francisco, CA, from April 28-May 2, 2012, for the American Association for Thoracic Surgery's 92nd Annual Meeting. This robust, high-quality five-day program, chaired by Craig R. Smith, MD, of the Columbia University, is designed with a primary focus on delivering cutting-edge education to improve cardiothoracic surgical practice. Join the world's leading scientists and medical professionals in the specialty at this premier continuing medical education event.

\section{Target Audience}

The AATS Annual Meeting is specifically designed to meet the educational needs of:

- Cardiothoracic Surgeons

- Physicians in related specialties including Cardiothoracic Anesthesia, Critical Care, Cardiology, Pulmonology, Radiology, Gastroenterology, Thoracic Oncology, and Vascular Surgery

- Fellows and Residents in Cardiothoracic and General Surgical training programs

- Allied Health Professionals involved in the care of cardiothoracic surgical patients including Nurses, Physician Assistants, Surgical Assistants, and Perfusionists

- Medical students with an interest in cardiothoracic surgery

\section{AATS Annual Meeting Accreditation}

The American Association for Thoracic Surgery is accredited by the Accreditation Council for Continuing Medical Education to provide continuing medical education for physicians.

This live activity has been approved for AMA PRA Category 1 Credit(s) ${ }^{\mathrm{TM}}$.

\section{CALL FOR ABSTRACTS}

The Abstract Deadline for the 92nd Annual Meeting is Tuesday, October 11, 2011, at 11:59 PM Eastern Daylight Time.

\section{Submission of Abstracts}

Authors submitting abstracts for the 92nd Annual Meeting must use electronic submission ONLY. Please visit the AATS Web site at www.aats.org/annualmeeting and select the Abstract Submission Link. Specific instructions for abstract submission are located on the Web site, including how to submit graphics and charts. Manuscripts are due in advance of the meeting for all accepted abstracts.

Residents are encouraged to submit basic science abstracts for the 15th Annual C. Walton Lillehei Resident Forum which will consist of presentations of original work by North American cardiothoracic surgical residents and/or residents in general surgical training programs who are working in a cardiothoracic surgical laboratory or clinical rotation. The presentations are selected by the AATS Research Scholarship Committee.

Presentation Types include:

- Regular Session

- Laboratory Research Forum

- Emerging Technologies Forum

- C. Walton Lillehei Resident Forum

Abstracts may be submitted for the following categories:

- Adult Cardiac

- Congenital

- General Thoracic

For further information on submitting an abstract for consideration, please visit www.aats.org or contact:

American Association for Thoracic Surgery

500 Cummings Center

Suite 4550, Beverly, MA, USA 01915

Telephone: +1 (978) 927-8330

Fax:+ 1 (978) 524-0498

E-mail: meetings@aats.org

\section{AATS Meetings and Sponsored Events www.aats.org}

September 8-10, 2011

International Society for Rotary Blood Pumps Annual Meeting*

Marriott Downtown

Louisville, Kentucky 